Pobrane z czasopisma Annales H - Oeconomia http://oeconomia.annales.umcs.pl Data: 26/04/2023 12:41:28

DOI:10.17951/h.2017.51.4.257

\begin{tabular}{lcc}
\hline \multicolumn{3}{c}{ A N N A L E S } \\
UNIVERSITATIS MARIAE CURIE-SKŁODOWSKA \\
LUBLIN - POLONIA \\
VOL. LI, 4 & SECTIOH H \\
\hline
\end{tabular}

Cracow University of Economics. Faculty of Finance and Law

ANNA MOŹDZIERZ

anna.mozdzierz@uek.krakow.pl

\title{
The Impact of Changes in Indirect Tax Rates on Inflation in Selected EU Countries
}

Wpływ zmian stawek podatków pośrednich na inflację w wybranych krajach UE

Keywords: indirect taxes; inflation; HICP; HICP at constant taxes

Słowa kluczowe: podatki pośrednie; inflacja; HICP; HICP przy stałych podatkach

JEL Code: E31; E62; G20

\section{Introduction}

The relationship between inflation and indirect taxes is bidirectional. Changes in the price level affect the tax revenues by influencing the tax base. A higher than expected rise in inflation results in an inflation premium, also called inflation tax, allowing for an improvement of the budget balance. Inflation is therefore called the "silent ally of the government" [Owsiak, 2017, p. 886]. Unexpected changes in inflation can cause fiscal loosening or tightening [Jabłecka, Jędrzejowicz, 2015, p. 20]. The inverse relationship between indirect taxes and inflation consists in the fact that changes in tax rates shape the prices. The fact that indirect taxes shape the prices can result in inflation phenomena.

Woźniak [2002, pp. 9-10], interpreting the definitions of inflation by Friedman [1968] as well as Laidler and Parkin [1975], concludes that a one-time bump in the prices due to changes in VAT rates cannot be called inflation. This is explained by the fact that these definitions do not apply to any increase in prices, but refer to an 
increase that is permanent and sustained over the long term. The concept of core inflation by Quah and Vahey [1995], in turn, regards the changes in tax rates as a source of non-core disturbances, determining the level of inflation.

The aim of the article is to identify the extent to which the price index in the $\mathrm{EU}$ countries was shaped by changes in indirect tax rates. The subject of research is all the more interesting given that the majority of EU countries decided to increase VAT rates and excise duties in response to the financial crisis. However, in many of them - paradoxically - a phenomenon of deflation occurred. Six countries with the biggest difference between HICP and HICP-CT were selected for an in-depth analysis of specific tax changes. The study covered the 2007-2016 period.

In order to ensure the comparability of data, the analysis was based on the harmonised index of consumer prices (HICP) and the harmonised index of consumer prices at constant tax rates (HICP-CT).

\section{Measuring inflation excluding the impact of the state on prices}

The state can impact prices through the use of administered prices or indirect taxation of goods and services. There are two indicators that enable the study of the impact of changes in indirect taxes on prices: the producer price index (PPI) and the harmonised consumer price index at constant tax rates (HICP-CT). PPI does not include indirect taxes, hence it reflects only the changes of prices determined by the producers at different stages of production. The advantages of PPI as an alternative measure of inflation have led some economists to suggest basing the direct inflation targeting strategy on this indicator [Ciżkowicz, 2012, p. 2]. In Poland, this indicator, in a modified form, is calculated by the Central Statistical Office. It has been based on producer prices in four sections: "Mining and quarrying", "Manufacturing", "Production and supply of electricity, gas, steam and hot water" and "Water supply, sewerage and waste management, reclamation". The absence of a harmonised method of calculating this indicator is also a disadvantage.

The harmonised index of consumer prices at constant tax rates (HICP-CT) is considered to be the best - although not flawless - measure for investigating the impact of changes in indirect tax rates that affect prices. The principles of their calculation are standardised in all EU countries and that enables comparability between countries. HICP-CT is defined as the ratio, which measures the changes in prices of consumer goods and services excluding the impact of changes in tax rates in the same period. The current rules for the calculation of the HICP-CT at national and EU level are specified in Regulation of the European Parliament and of the Council (EU) 2016/792 of 11 May 2016.

HICP-CT data is broken down into categories of the European classification of individual consumption by purpose (ECOICOP), which enables the creation of sub-indices. 
Basic pieces of information necessary for their calculations are: a) purchase prices of products, $b$ ) characteristics that determine the product price, c) information on taxes and excise duties levied, d) information as to whether a price is fully or partially administered, e) weights reflecting the level and structure of the consumption of the products concerned.

This measure is interesting from a cognitive point of view, it is, however, hypothetical, as it assumes an immediate impact of changes in indirect taxes on prices. The methodology ignores the time delays. Furthermore, in reality, an increase in VAT rates can make the sellers increase the prices of goods and services to a lesser extent than it results from the increase in rates, due to the competition on the market. Hence, the HICP at constant tax rates helps to identify the potential impact of tax changes on product price index, setting its upper limit.

\section{The impact of indirect taxes on the HICP in the EU countries}

The article uses the definition of indirect taxes adopted in the methodology of the European Commission [2016a, p. 296]. Indirect taxes are the taxes on production and imports, which include VAT, excise taxes and duties related to import, other taxes on products and other taxes on production. During the crisis, the majority of EU countries, in order to gain additional revenue, decided to increase the VAT and excise duties, as well as to introduce new taxes on consumption. Fiscal policy had an impact on prices. In Table 1, I calculated the impact of changes in indirect taxes on annual HICP inflation rates in the EU countries.

Table 1. The impact of changes in indirect taxes on the annual rate of HICP inflation (annual percentage changes; HICP from December to December), 2007-2016

\begin{tabular}{|l|c|c|c|c|c|c|c|c|c|c|c|c|}
\hline \multicolumn{1}{|c|}{ Country } & 2007 & 2008 & 2009 & 2010 & 2011 & 2012 & 2013 & 2014 & 2015 & 2016 & $\begin{array}{c}\text { Average } \\
2007- \\
2016\end{array}$ & $\begin{array}{c}\text { Average } \\
2008- \\
2012\end{array}$ \\
\hline Romania & 0.7 & 0.9 & 1.7 & 5.7 & 0.2 & 0.1 & -0.1 & 0.7 & -3.0 & -1.9 & 0.5 & 1.7 \\
\hline Latvia & 0.4 & 1.4 & 5.1 & -0.1 & 1.8 & -0.6 & 0.1 & 0.2 & 0.2 & 0.6 & 0.9 & 1.5 \\
\hline Greece & 0.1 & 0.1 & 0.5 & 4.3 & 1.4 & 0.7 & -0.9 & -0.3 & 1.9 & 0.7 & 0.9 & 1.4 \\
\hline Hungary & 0.2 & 0.1 & 3.7 & 0.4 & 0.8 & 1.9 & 0.3 & 0.0 & 0.2 & -0.1 & 0.8 & 1.4 \\
\hline Lithuania & 0.3 & 1.1 & 5.3 & 0.0 & 0.0 & 0.2 & 0.0 & 0.1 & 0.1 & 0.2 & 0.7 & 1.3 \\
\hline Estonia & 0.5 & 2.1 & 1.9 & 0.5 & 0.2 & 0.2 & 0.2 & 0.3 & 0.3 & 0.8 & 0.7 & 1.0 \\
\hline Czech Republic & 0.6 & 1.8 & 0.1 & 1.2 & 0.1 & 1.3 & 0.9 & 0.1 & 0.2 & 0.0 & 0.6 & 0.9 \\
\hline Spain & 0.0 & -0.1 & 0.3 & 1.2 & -0.1 & 2.1 & 0.1 & 0.0 & 0.0 & 0.0 & 0.4 & 0.7 \\
\hline United Kingdom & 0.2 & -1.0 & 0.3 & 1.8 & 1.6 & 0.2 & 0.1 & 0.0 & 0.0 & 0.1 & 0.3 & 0.6 \\
\hline Bulgaria & 0.2 & 0.8 & 0.6 & 1.1 & -0.2 & 0.0 & 0.0 & 0.0 & 0.0 & 0.3 & 0.3 & 0.5 \\
\hline Croatia & -0.2 & 0.0 & 1.3 & 0.2 & -0.1 & 1.1 & 0.6 & 0.5 & 0.4 & 0.1 & 0.4 & 0.5 \\
\hline
\end{tabular}


Pobrane z czasopisma Annales H - Oeconomia http://oeconomia.annales.umcs.pl

Data: 26/04/2023 12:41:28

ANNA MOŹDZIERZ

\begin{tabular}{|l|c|c|c|c|c|c|c|c|c|c|c|c|}
\hline \multicolumn{1}{|c|}{ Country } & 2007 & 2008 & 2009 & 2010 & 2011 & 2012 & 2013 & 2014 & 2015 & 2016 & $\begin{array}{c}\text { Average } \\
2007- \\
2016\end{array}$ & $\begin{array}{c}\text { Average } \\
2008- \\
2012\end{array}$ \\
\hline Poland & 0.6 & 0.8 & 0.7 & 0.2 & 0.8 & 0.2 & 0.3 & 0.4 & 0.0 & 0.0 & 0.4 & 0.5 \\
\hline Slovenia & -0.1 & 0.2 & 1.2 & 0.3 & -0.1 & 1.0 & 1.1 & 0.6 & -0.2 & 0.0 & 0.4 & 0.5 \\
\hline Cyprus & -0.7 & 0.1 & 0.0 & 0.5 & 0.3 & 1.1 & 0.7 & 1.1 & 0.0 & 0.0 & 0.3 & 0.4 \\
\hline Netherlands & 0.1 & 0.4 & 0.0 & 0.1 & 0.3 & 1.1 & 0.6 & 0.2 & 0.3 & 0.0 & 0.3 & 0.4 \\
\hline Denmark & -0.2 & 0.2 & -0.1 & 0.7 & 0.3 & 0.5 & -0.2 & 0.2 & -0.1 & 0.0 & 0.1 & 0.3 \\
\hline Ireland & 0.2 & 0.8 & 0.3 & -0.4 & -0.2 & 0.9 & 0.8 & 0.1 & 0.2 & 0.2 & 0.3 & 0.3 \\
\hline Italy & 0.0 & 0.0 & 0.0 & 0.2 & 0.9 & 0.4 & 0.3 & 0.1 & 0.0 & 0.0 & 0.2 & 0.3 \\
\hline Luxembourg & 0.3 & 0.0 & 0.5 & 0.2 & 0.0 & 0.6 & 0.1 & 0.2 & 1.2 & 0.1 & 0.3 & 0.3 \\
\hline Slovakia & 0.0 & 0.3 & 0.2 & 0.0 & 0.9 & 0.2 & 0.0 & 0.0 & 0.0 & -0.4 & 0.1 & 0.3 \\
\hline Finland & -0.2 & 0.3 & -0.2 & 0.3 & 0.4 & 0.8 & 0.7 & 0.5 & 0.3 & 0.2 & 0.3 & 0.3 \\
\hline Malta & -0.3 & 0.2 & 0.1 & 0.1 & 0.2 & 0.0 & 0.3 & 0.2 & 0.3 & 0.7 & 0.2 & 0.1 \\
\hline Austria & 0.2 & 0.1 & 0.0 & 0.0 & 0.5 & 0.0 & 0.0 & 0.1 & 0.0 & 0.1 & 0.1 & 0.1 \\
\hline Sweden & 0.5 & 0.6 & 0.2 & 0.0 & -0.1 & -0.4 & 0.2 & 0.1 & 0.1 & 0.1 & 0.1 & 0.1 \\
\hline Belgium & 0.2 & 0.0 & 0.2 & -0.3 & 0.1 & 0.2 & 0.2 & -0.3 & 0.6 & 0.6 & 0.2 & 0.0 \\
\hline Germany & 1.5 & 0.0 & 0.1 & -0.2 & 0.1 & -0.1 & 0.1 & -0.1 & 0.1 & 0.0 & 0.2 & 0.0 \\
\hline
\end{tabular}

Note: Due to the lack of data for France and Portugal on the HICP-CT, these countries have been omitted from the analysis.

Source: own calculations on the basis of: [Eurostat].

This impact corresponds to the difference between the HICP and HICP-CT for the same period. Due to the simplification of neglecting the impact of time delays in the methodology of the European Central Bank, this effect is referred to as "average mechanical impact" [EBC, 2011, p. 64]. Countries are listed in descending order by the average magnitude of impact in the 2008-2012 period, when most tax increases were introduced, and which had a direct relationship to the financial crisis. The average values indicate that changes in indirect tax rates most strongly shaped the growth rate of prices in Romania, and the least in Germany and Belgium. One should pay particular attention to the results for Latvia, Hungary and Lithuania in 2009, and Romania and Greece in 2010, where the upper limits of the impact of tax changes on inflation are in the $3.7 \%$ to $5.7 \%$ range.

On the basis of the analysis of the data contained in Table 1, the countries where the average impact of changes in taxes on the HICP in the 2008-2012 period was $1 \%$ or more have been selected for an in-depth study. These are: Romania, Greece, Hungary and the Baltic countries.

The strength of the impact of tax policy on inflation is determined by the structure of the tax system in a given country. The data in Table 2 shows that in all countries selected for the study, the share of indirect taxes in total tax revenue is higher than the average for the euro area and the EU. Compared with the euro area countries, this share in 2015 in Hungary and Romania was higher by approx. 15 percentage points. 
Pobrane z czasopisma Annales H - Oeconomia http://oeconomia.annales.umcs.pl Data: 26/04/2023 12:41:28

THE IMPACT OF CHANGES IN INDIRECT TAX RATES ON INFLATION...

Table 2. The share of indirect taxes in tax revenue (including social security contributions) 2007-2015

\begin{tabular}{|l|c|c|c|c|c|c|c|c|c|}
\hline \multicolumn{1}{|c|}{ Country } & 2007 & 2008 & 2009 & 2010 & 2011 & 2012 & 2013 & 2014 & 2015 \\
\hline Hungary & 40.3 & 39.7 & 42.2 & 47.1 & 47.5 & 48.6 & 48.7 & 48.7 & 48.2 \\
\hline Romania & 43.3 & 42.6 & 41.0 & 45.3 & 46.5 & 47.5 & 46.8 & 46.6 & 47.5 \\
\hline Greece & 39.9 & 39.9 & 38.4 & 39.7 & 40.4 & 38.4 & 40.0 & 43.8 & 44.3 \\
\hline Latvia & 42.5 & 38.5 & 40.0 & 42.2 & 42.2 & 42.3 & 43.0 & 43.9 & 44.1 \\
\hline Lithuania & 39.6 & 38.9 & 39.1 & 42.5 & 43.4 & 42.1 & 41.7 & 41.7 & 44.1 \\
\hline Estonia & 43.3 & 39.0 & 42.0 & 41.8 & 43.2 & 43.9 & 42.6 & 43.2 & 42.9 \\
\hline EU28 & 34.6 & 33.7 & 33.9 & 34.9 & 35.0 & 35.0 & 34.8 & 35.1 & 34.9 \\
\hline EA19 & 33.4 & 32.5 & 32.7 & 33.2 & 33.1 & 33.0 & 32.7 & 33.0 & 32.8 \\
\hline
\end{tabular}

Source: [Eurostat].

Moreover, while in the euro area from 2007 to 2015, the share of indirect taxes in total income has decreased, in Hungary it has increased by approx. 8 percentage points (8.9\% in 2008-2012), and in Romania, Greece and Lithuania by more than 4 percentage points. In Estonia, the increase in the share of indirect taxes of nearly 5 percentage points has been observed in the 2008-2012 period.

The increase in taxes that influence prices has affected the price index, which is illustrated in Chart 1.

State's influence on prices through indirect taxes in different years of the studied period resulted in increasing or decreasing inflation. A strong correlation between increases in indirect taxes and inflation in Greece is confirmed by empirical research carried out by Koutsouvelis and Papastathopoulos [2013, p. 61], which demonstrates that changes in tax rates were responsible for the HICP measure in $82 \%$ in 2010 , and $60.7 \%$ in 2011.

It is worth noting, however, that in 2009 , tax increases have prevented the Baltic states from potential deflation, which would have occurred, had the changes in tax policy not been introduced. For example, in Lithuania the HICP was at 1.2\% and the HICP at constant taxes $-4.1 \%$. In turn, the Latvian tax policy in 2009 resulted in a reduction of deflation by 5.1 percentage points.

Chart 1 shows that the biggest differences between the HICP and the HICP-CT occurred in the 2008-2012 period, therefore later in the paper, I identify the changes in the tax systems, which caused these differences. 
Pobrane z czasopisma Annales $\mathrm{H}$ - Oeconomia http://oeconomia.annales.umcs.pl Data: 26/04/2023 12:41:28
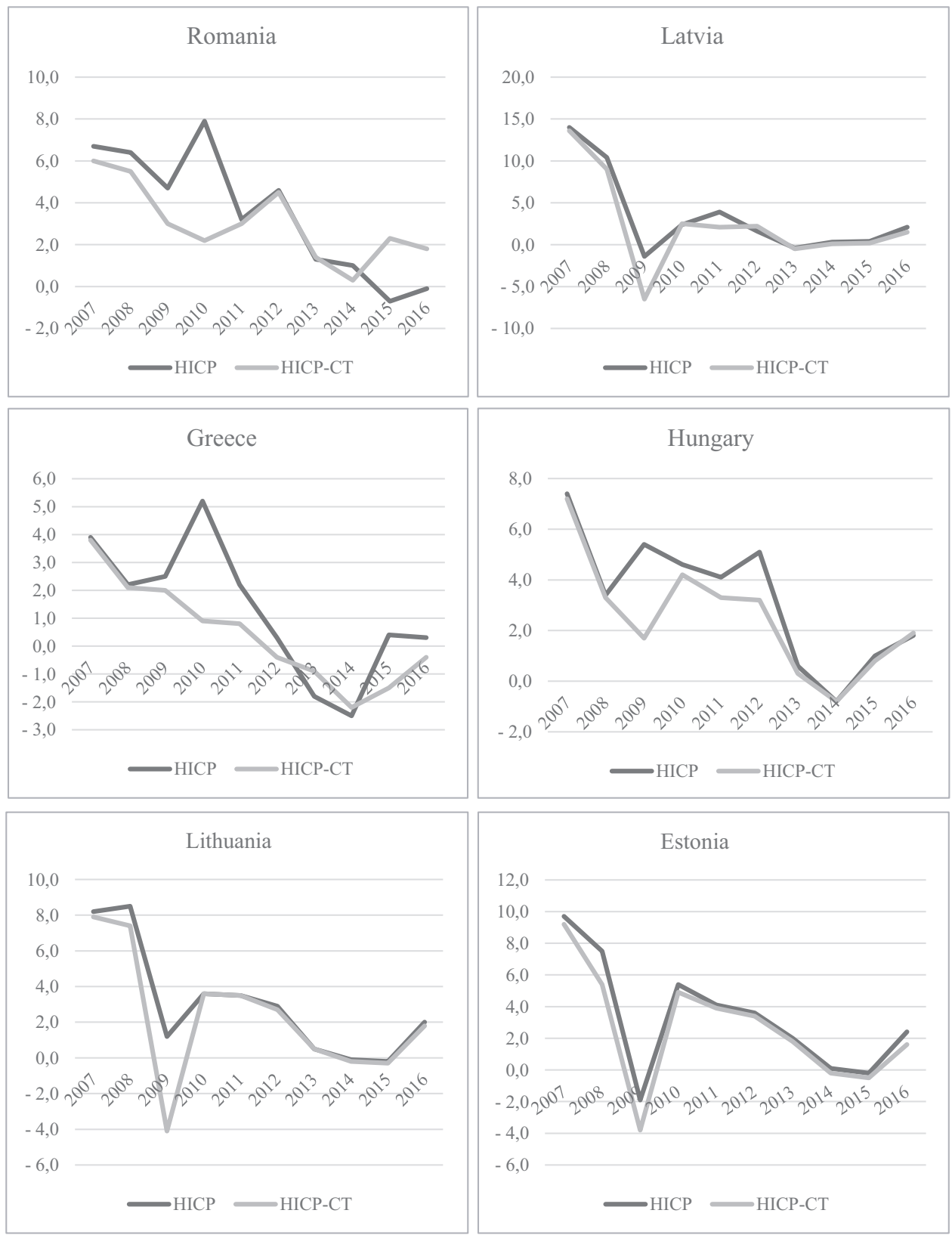

Chart 1. HICP and HICP-CT (from December to December, 2015=100), 2007-2016

Source: own study based on: [Eurostat]. 


\section{Changes in indirect tax rates in selected $\mathbf{E U}$ countries}

In response to the financial crisis, all studied countries increased VAT rates. In the Baltic countries, the increases occurred in 2009. Estonia raised its standard rate by 2 percentage points to $20 \%$, and the reduced rate by 4 percentage points, from $5 \%$ to $9 \%$, while Lithuania from $8 \%$ to $21 \%$. They remained at this level until the end of the observation period. Latvia raised its standard rate by 4 percentage points, from $18 \%$ to $22 \%$ and the reduced rate from $5 \%$ to $12 \%$. Improved economic situation led to a small reduction in the standard rate by 1 percentage point in 2012, which had a positive impact on reducing the HICP that year (Table 1).

In Greece, the strongest impact on inflation (4.5\%) had an increase in VAT rates in 2010 . The standard rate has increased from $19 \%$ to $23 \%$ and remained at this level in subsequent years. The reduced rates were increased twice in $2010(4.5 \%$ and $9 \%$ to $5.5 \%$ and $11 \%)$ and in $2011(6.5 \%$ and $13 \%)$. In Romania, a strong impact $(5.7 \%)$ on the price index in 2010 was caused by an increase in the standard rate by 5 percentage points, from $19 \%$ to $24 \%$. In 2016 , this rate was lowered to $20 \%$, which weakened inflationary pressure and contributed to a reduction in the HICP by 1.9 percentage points. Similarly to Romania, in Hungary, the standard rate increased by 5 percentage points in 2009 to $25 \%$. At the same time, in addition to the $5 \%$ reduced rate, a new reduced rate of $18 \%$ has been introduced. Fiscal decisions of 2009 explain, to a large extent, the difference between HICP and HICP-CT of 3.7 percentage points. Another strong impact of tax rate increases on the price index was observed in 2012, $(1.9 \%)$, which was caused by the second rise in the standard VAT rate to $27 \%$. Moreover, in the 2010-2015 period, Hungary has introduced a number of indirect taxes other than VAT and excise duties, e.g. insurance tax, tax on car accidents, telecommunications tax, tax related to public health, tax on overground and underground networks, tax on solar panels ${ }^{1}$.

The study demonstrated that excise tax was an effective tool for raising additional revenue. Changes in excise rates had bigger impact on the price than VAT, hence the study of tax policy in this area will explain the impact of taxes on the HICP in the period, in which VAT increases have not occurred. For this purpose, Table 3 contains the excise tax rates in 2007, 2012 and 2016. Their analysis shows that the excise tax rates have increased significantly during the studied period in all countries, thus, leading to an increase in the general price index.

1 Hungarian tax policy in the 2003-2016 period has been described in detail in: [Moździerz, 2016, pp. 229-277]. 
Pobrane z czasopisma Annales H - Oeconomia http://oeconomia.annales.umcs.pl

Data: 26/04/2023 12:41:28

ANNA MOŹDZIERZ

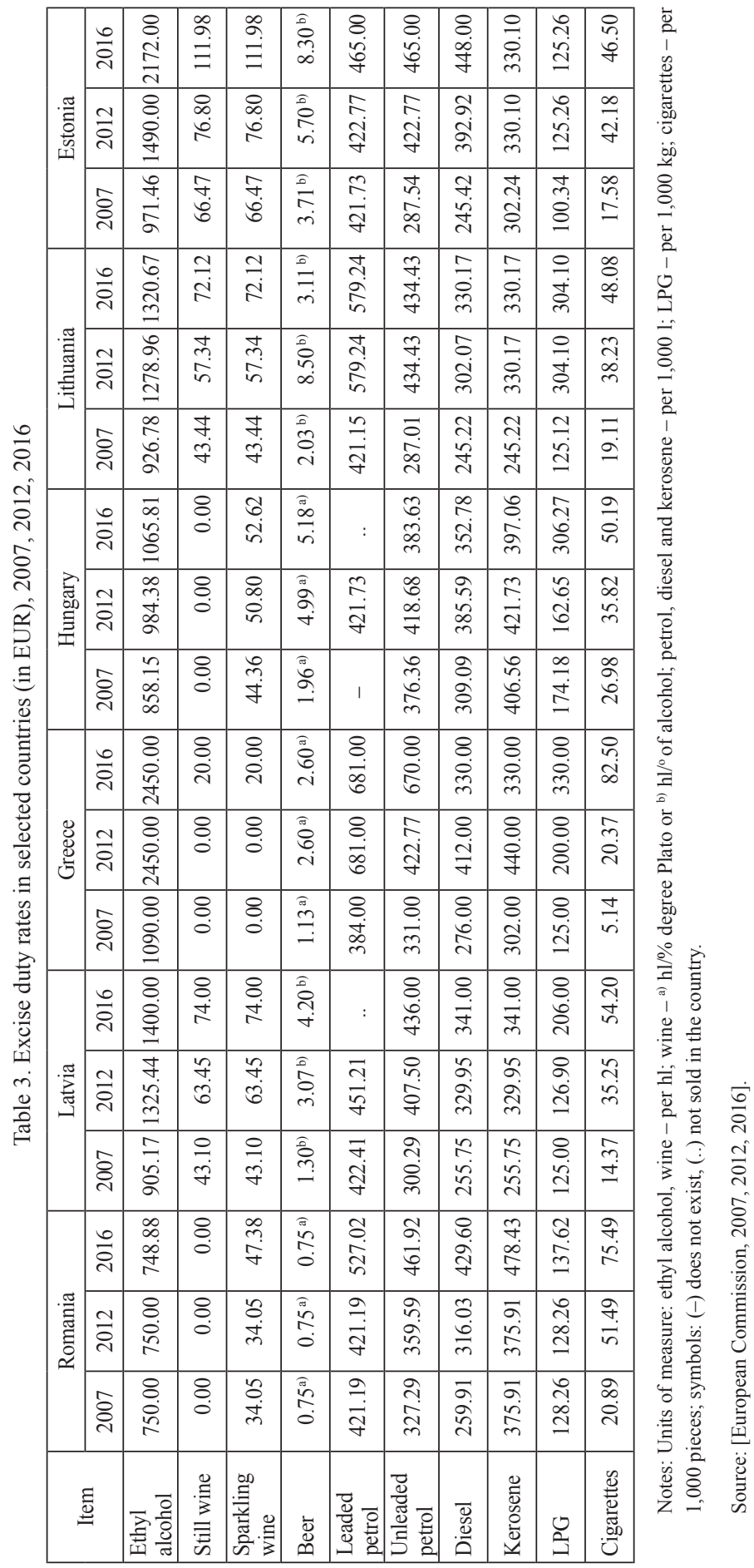


The calculations in Table 4 show that in the last decade, the rates of excise duty have increased significantly. A high increase in the rate for cigarettes in Greece was due to the increase of excise duty from EUR 5.14 in 2007 to EUR 82.50 in 2016 (per 1,000 pieces).

Table 4. Changes in tax rates between 2012 and 2007, and 2016 and 2007 (\%)

\begin{tabular}{|l|r|r|r|r|r|r|r|r|r|r|r|r|}
\hline \multirow{2}{*}{ Item } & \multicolumn{2}{|c|}{ Romania } & \multicolumn{2}{c|}{ Latvia } & \multicolumn{2}{c|}{ Greece } & \multicolumn{2}{c|}{ Hungary } & \multicolumn{2}{c|}{ Lithuania } & \multicolumn{2}{c|}{ Estonia } \\
\cline { 2 - 14 } & \multicolumn{1}{c|}{$\mathrm{A}$} & \multicolumn{1}{c|}{$\mathrm{B}$} & \multicolumn{1}{c|}{$\mathrm{A}$} & \multicolumn{1}{c|}{$\mathrm{B}$} & \multicolumn{1}{c|}{$\mathrm{A}$} & \multicolumn{1}{c|}{$\mathrm{B}$} & \multicolumn{1}{c|}{$\mathrm{A}$} & \multicolumn{1}{c|}{$\mathrm{B}$} & \multicolumn{1}{c|}{$\mathrm{A}$} & \multicolumn{1}{c|}{$\mathrm{B}$} & \multicolumn{1}{c|}{$\mathrm{A}$} & $\mathrm{B}$ \\
\hline Ethyl alcohol & 0.0 & -0.1 & 46.4 & 54.7 & 124.8 & 124.8 & 14.7 & 24.2 & 38.0 & 42.5 & 53.4 & 123.6 \\
\hline Still wine & 0.0 & 0.0 & 47.2 & 71.7 & 0.0 & 0.0 & 0.0 & 0.0 & 32.0 & 66.0 & 15.5 & 68.5 \\
\hline $\begin{array}{l}\text { Sparkling } \\
\text { wine }\end{array}$ & 0.0 & 39.1 & 47.2 & 71.7 & 0.0 & 0.0 & 14.5 & 18.6 & 32.0 & 66.0 & 15.5 & 68.5 \\
\hline Beer & 0.0 & -0.1 & 136.2 & 223.1 & 130.1 & 130.1 & 154.1 & 163.7 & 318.7 & 53.2 & 53.6 & 123.7 \\
\hline $\begin{array}{l}\text { Leaded } \\
\text { petrol }\end{array}$ & 0.0 & 25.1 & 6.8 &.. & 77.3 & 77.3 &.. &.. & 37.5 & 37.5 & 0.2 & 10.3 \\
\hline $\begin{array}{l}\text { Unleaded } \\
\text { petrol }\end{array}$ & 9.9 & 41.1 & 35.7 & 45.2 & 27.7 & 102.4 & 11.2 & 1.9 & 51.4 & 51.4 & 47.0 & 61.7 \\
\hline Diesel & 21.6 & 65.3 & 29.0 & 33.3 & 49.3 & 19.6 & 24.8 & 14.1 & 23.2 & 34.6 & 60.1 & 82.5 \\
\hline Kerosene & 0.0 & 27.3 & 29.0 & 33.3 & 45.7 & 9.3 & 3.7 & -2.3 & 34.6 & 34.6 & 9.2 & 9.2 \\
\hline LPG & 0.0 & 7.3 & 1.5 & 64.8 & 60.0 & 164.0 & -6.6 & 75.8 & 143.0 & 143.0 & 24.8 & 24.8 \\
\hline Cigarettes & 146.5 & 261.4 & 145.3 & 277.2 & 296.1 & 1504.2 & 32.8 & 86.0 & 100.1 & 151.6 & 139.9 & 164.5 \\
\hline
\end{tabular}

Note: Changes between: A (2012 and 2007), B (2016 and 2007).

Source: own calculations on the basis of Table 3 data.

With this in mind, it is interesting that in the discussions on the changes in indirect taxes, attention is generally focused on VAT rates and increases of excise duties are usually hardly mentioned.

\section{Conclusions}

In the modern economy, the state (government) has limited impact on prices. This impact, however, is possible through the use of administered prices and changes in indirect taxes. The experience from the last crisis shows that changes in indirect taxes in some countries shaped, to a large extent, the growth rate of prices. It resulted in increased or decreased inflation, and in the case of some countries in reduced deflation. On the basis of the study of Romania, Hungary, Greece and the Baltic countries one can conclude that the structure of the tax system with a high proportion of indirect taxes equips fiscal authorities with tools to influence the prices. Reconstruction of the tax system towards an even distribution of taxation between direct and indirect taxes would help reducing inflationary pressures. Limiting the phenomenon of fiscal illusions that occur with indirect taxes would be an additional advantage. 


\section{Bibliography}

Ciżkowicz M., Strategia bezpośredniego celu inflacyjnego. Alternatywne mierniki inflacji, Instytut Ekonomiczny NBP, Warszawa 2012.

EBC, Biuletyn miesięczny EBC, Frankfurt nad Menem, marzec 2011.

European Commission, Excise duty tables, European Commission, DG Taxation and Customs Union Tax Policy, Brussels, July, REF 1.025, 2007, http://ec.europa.eu/taxation_customs/index_enhtm\# [access: 13.02.2017].

European Commission, Excise duty tables, European Commission, DG Taxation and Customs Union Tax Policy, Brussels, January, REF 1.034, 2012, http://ec.europa.eu/taxation_customs/index_enhtm\# [access: 13.02.2017].

European Commission, Excise duty tables, European Commission, DG Taxation and Customs Union Tax Policy, Brussels, January, REF 1045 rev 1, 2016, http://ec.europa.eu/taxation_customs/index_enhtm\# [access: 13.02.2017].

European Commission, Taxation Trends in the European Union, Data for The EU Member States, Iceland and Norway, DG Taxation and Customs Union, Luxembourg: Publications Office of the European Union, 2016a.

Eurostat, http://ec.europa.eu/eurostat/data/database [access: 12.02.2017].

Friedman M., The Role of Monetary Policy, "The American Economic Review” 1968, Vol. 58(1).

Jabłecka A., Jędrzejowicz T., Wptyw zmian inflacji na finanse publiczne i politykę fiskalna w Polsce, Instytut Ekonomiczny NBP, Warszawa 2015.

Koutsouvelis P., Papastathopoulos A., The Effects of Indirect Taxes on Consumer Prices: Empirical Evidence for Greece, "Advances in Management \& Applied Economics" 2013, Vol. 3, No. 1.

Laidler D., Parkin M., Inflation: A Survey, "The Economic Journal” 1975, Vol. 85(340),

DOI: https://doi.org/10.2307/2230624.

Moździerz A., Kraje Grupy Wyszehradzkiej, [w:] S. Owsiak (red.), Polityka podatkowa krajów Unii Europejskiej, Warszawa 2016.

Owsiak S., Finanse publiczne. Współczesne ujęcie, PWN, Warszawa 2017.

Quah D., Vahey S.P., Measuring Core Inflation, “The Economic Journal” 1995, Vol. 105(432),

DOI: https://doi.org/10.2307/2235408.

Rozporządzenie Parlamentu Europejskiego i Rady (UE) 2016/792 z dnia 11 maja 2016 r. w sprawie zharmonizowanych wskaźników cen konsumpcyjnych oraz wskaźnika cen nieruchomości mieszkalnych i uchylające rozporządzenie Rady (WE) nr 2494/95 (Dz.Urz. UE nr L 135/11).

Woźniak P., Inflacja bazowa, CASE, Warszawa 2002.

\section{Wpływ zmian stawek podatków pośrednich na inflację w wybranych krajach UE}

Celem artykułu jest rozpoznanie, w jakim stopniu w krajach UE poziom wskaźnika cen był kształtowany pod wpływem zmian stawek podatków pośrednich. W celu porównywalności danych analizę przeprowadzono w oparciu o zharmonizowany wskaźnik cen konsumpcyjnych (HICP) oraz zharmonizowany wskaźnik cen konsumpcyjnych przy stałych stawkach podatkowych (HICP-CT). Do pogłębionych analiz, mających na celu rozpoznanie wprowadzonych zmian stawek VAT i podatku akcyzowego, wybrano sześć krajów, dla których różnica między HICP a HICP-CT była najwyższa: Rumunia, Węgry, Grecja i kraje nadbałtyckie. Obserwacją objęto dekadę 2007-2016. Na podstawie przeprowadzonych badań można wnioskować, że struktura systemu podatkowego, z wysokim udziałem podatków pośrednich, wyposaża władze fiskalne w istotne możliwości kształtowania poziomu cen. 
Pobrane z czasopisma Annales H - Oeconomia http://oeconomia.annales.umcs.pl Data: 26/04/2023 12:41:28

THE IMPACT OF CHANGES IN INDIRECT TAX RATES ON INFLATION...

\section{The Impact of Changes in Indirect Tax Rates on Inflation in Selected EU Countries}

The aim of the article is to identify the extent to which the price index in the EU countries was shaped by changes in indirect tax rates. In order to ensure the comparability of data, the analysis was based on the harmonised index of consumer prices (HICP) and the harmonised index of consumer prices at constant tax rates (HICP-CT). Six countries with the biggest difference between the HICP and HICP-CT were selected for an in-depth analysis of changes in VAT and excise duties: Romania, Hungary, Greece and the Baltic countries. The study covered the 2007-2016 period. On the basis of the study one can conclude that the structure of the tax system with a high proportion of indirect taxes equips fiscal authorities with tools to influence the prices. 